\title{
Comparison of Bacterial DNA Extraction Methods From Stool Samples for Quantitative Real-Time PCR Analysis
}

\section{Dışkı Örneklerinde Real-Time PCR Analizleri için Bakteriyel DNA Izolasyon Yöntemlerinin Karşılaştırılması}

\section{Ceren ÖZKUL ${ }^{\circ}$}

Hacettepe University, Faculty of Pharmacy, Department of Pharmaceutical Microbiology, Sihhiye, Ankara, Turkey.

\section{ABSTRACT}

The most crucial step in molecular microbiology studies is choosing an appropriate procedure to obtain sufficient, highquality DNA. Two commercially available kits (QIAamp DNA Stool Mini Kit, Qiagen and PSP Spin Stool DNA Plus Kit, Invitek) and a modified in-house phenol-chloroform extraction method was compared for their efficiency in isolation of certain bacteria from human stool samples for Real-Time GPCR. DNA yield was significantly higher in Invitek when compared to other methods. Spiking experiments and GPCR results revealed that efficiency was in phenol-chloroform extraction was lower when compared to other two commercial kits. Commercial kits have better results in terms of DNA recovery and purity, and have more accurate results for qPCR experiments.

\section{Key Words}

qPCR, DNA extraction, stool, phenol-chloroform.

M oleküler mikrobiyoloji çalışmalarında en önemli basamak yüksek kalitede yeterli DNA eldesidir. Bu çalışmada iki hazır ticari izolasyon kiti (QIAamp DNA Stool Mini Kit, Qiagen and PSP Spin Stool DNA Plus Kit, Inivtek) ve modifiye fenol-kloroform ekstraksiyon yöntemi Real-Time qPCR analizleri için belirli bakterilerin dışkıdan izolasyonundaki etkinleri bakımından karşılaştırılmıştır. DNA miktarı Invitek kitinde en yüksek oranda elde edilmiştir. Dışkıya ve PCR karışımına bilinen miktarda hücre ve DNA eklenme deneyleri ve qPCR sonuçları fenol-kloroform ekstraksiyon yönteminin etkinliğinin düşük olduğunu göstermiştir. Hazır ticari dışkıdan izolasyon kitleri DNA eldesi ve saflığı açsıından qPCR deneylerinde kullanılmak üzere daha doğru sonuçlar vermektedir.

\section{Anahtar Kelimeler}

qPCR, DNA izoalsyonu, dışkı, fenol-kloroform.

Article History: Mar 11, 2019; Revised: Oct 16, 2019; Accepted: Oct 20, 2019; Available Online: Jan 1, 2020.

DOI: $\underline{\text { https://doi.org/10.15671/hjbc.538110 }}$

Correspondence to: C.Özkul, Hacettepe University, Faculty of Pharmacy, Department of Pharmaceutical Microbiology, Sıhhiye, Ankara, Turkey. E-Mail: cerenozkul@hacettepe.edu.tr 


\section{INTRODUCTION}

Ta he effect of human gut microbiota on both health and several disease pathogenesis has been emerged in recent years. Data provided from Human Microbiome Project and MetaHit Consortium has enabled the understanding of gut microbiota composition and functions both in health and pathological conditions. [1, 2]. The gut microbiota can be named as a major metabolic organ composed of >1014 microorganisms including approximately 500-1000 species. The number of microorganisms as well as the predominant species significantly differs among individuals [3]. Moreover the dietary habits, life standards, genetic predisposition and use of antibiotics also affects gut microbiota [4-6]. Due to this diversity, the better understanding of microbiota has become an increasingly emerging field and extensive efforts have been made to determine this complex ecosystem.

Culture-independent molecular techniques provide wide information about the composition and abundance of the human microbiota $[7,8]$. Particularly, the high throughput sequencing of 16S rRNA gene by using next generation sequencing technologies has been shed light on the human microbiota $[1,2]$. By the introducement of next generation sequencing techniques the specific microbial populations in various diseases has also been enlighten $[6,9,10]$.

Despite the advantages of $16 \mathrm{~S}$ rRNA gene amplicon sequencing in microbiome studies, it also has various limitations including sequencing errors, variable results among different regions chosen, difficulties in assessing operational taxonomic units and in defining bacteria in species level as well as the limited discriminative power among closely related species [11, 12]. Among the molecular techniques, quantitative real-time PCR is reliable, reproducible and sensitive method for the specific detection of bacterial species, bacterial groups in family level such as Enterobacteriaceae as well as total $16 \mathrm{~S}$ rRNA in complex bacterial ecosystems [13-17]. This method may provide a better understanding of microbial abundance and may be used to confirm the significant results of $16 \mathrm{~S}$ rRNA sequencing.

A crucial step in all molecular approaches is to obtain sufficient, high-quality DNA [18]. In Real-Time qPCR experiments extraction procedure is particularly important in order to obtain accurate results for absolute quantification. It has been widely known that DNA isolation and purification from stool samples is a challenging process due to the inhibitory content [19].

There has been increasing evidence that different extraction procedures may have different results in terms of amount and quality of extracted DNA [20]. Since this is especially important in Real time qPCR studies, the aim of the present study is to compare the GPCR results of important bacterial groups in gut microbiota, in which the bacterial DNA was extracted using three different methods.

\section{MATERIALS and METHODS}

\section{Collection of Stool Samples and Storage}

Total of 12 stool samples from healthy volunteers were included into the present study. Patients were carefully instructed as to collect stool samples. The stool samples were immediately stored at $-86^{\circ} \mathrm{C}$ until the study day.

\section{Evaluation of DNA recovery and PCR inhibitors}

For spiking experiments, mobile colistin resistance (mcr-1) gene carrying strain E. coli NCTC 13846 was used, since it is not expected to present in normal flora. In order to evaluate the extraction efficiency, colonies from pure cultures of E. coli NCTC 13846 were spiked into stool samples before all extraction procedures. For identifying possible inhibitory compounds, known amounts of E. coli NCTC 13846 DNA, which was extracted as described below, were spiked into the samples after extraction prior to PCR experiments. For quantitative determination of E. coli NCTC 13846, mcr-1 gene specific primers with primer sequences presented in Table 1 was used.

\section{DNA Extraction Procedures}

Prior to extraction of bacterial DNA, $200 \mathrm{mg}$ of stool was weighted into $1.5 \mathrm{~mL}$ microcentrifuge tubes. Commercial kits including QIAamp DNA Stool Mini Kit (Qiagen, Hilden, Germany), PSP Spin Stool Kit (Invitek, Berlin, Germany) and a manual phenol-chloroform extraction method was used for DNA isolation from stool samples. Protocols for commercial kits were performed according to manufacturers instructions, except the initial step, stool weighting. The initial stool weight was 200 $\mathrm{mg}$ for all the protocols in order to optimize the quantification steps. 
Table 1. Physical data of chiral amide-Schiff bases (3-9).

\begin{tabular}{|c|c|c|c|c|}
\hline Bacterium & Primer Sequence $\left(5^{\prime}-3^{\prime}\right)$ & $\begin{array}{l}\text { Target } \\
\text { (bp) }\end{array}$ & Annealing $\left({ }^{\circ} \mathrm{C}\right)$ & $\mathrm{Tm}$ \\
\hline Bifidobacterium spp. & $\begin{array}{c}\text { CTCCTGGAAACGGGTGGGGTGTTCTTCCCGATATCTACA } \\
\text { GGTGTTCTTCCCCATATCTACA }\end{array}$ & 550 & 56 & 90 \\
\hline Lactobacillus spp. & $\begin{array}{l}\text { AGCAGTAGGGAATCTTCCA } \\
\text { CACCGCTACACATGGAG }\end{array}$ & 341 & 55 & 86 \\
\hline A. muciniphila & $\begin{array}{l}\text { CAGCACGTGAAGGTGGGGAC } \\
\text { CCTTGCGGTTGGCTTCAGAT }\end{array}$ & 327 & 60 & 90 \\
\hline F. prausnitzii & $\begin{array}{l}\text { GATGGCCTCGCGTCCGATTAG } \\
\text { CCGAAGACCTTCTTCCTCC }\end{array}$ & 199 & 60 & 88 \\
\hline Enterobacteriaceae & $\begin{array}{l}\text { CATTGACGTTACCCGCAGAAGAAGC } \\
\text { CTCTACGAGACTCAAGCTTGC }\end{array}$ & 195 & 63 & 87 \\
\hline E. coli NCTC 13846 & $\begin{array}{l}\text { AGTCCGTTTGTTCTTGTGGC } \\
\text { AGATCCTTGGTCTCGGCTTG }\end{array}$ & 320 & 58 & 98 \\
\hline
\end{tabular}

A modified phenol-chloroform method, which depends on mechanical and chemical principle for cell lysis, and precipitation principle for DNA recovery was used for in-house DNA extraction.

Phenol-chloroform extraction protocol was modified from Zoetendal et al. [20]. Briefly; $200 \mathrm{mg}$ stool samples were weighted into sterile microcentrifuge tubes containing $0.1 \mathrm{~mm}$ zirconia beads (Biospec Products, Bartlesville, OK, USA), $12 \mu \mathrm{L}$ Proteinase $\mathrm{K}$ and $100 \mu \mathrm{L}$ SDS solution followed by an incubation step for 1 hour at $550 \mathrm{C}$. After the bead-beating steps by adding phenolchloroform in equal volumes followed by precipitation steps by using isopropanol.

\section{Real-Time PCR Experiments}

As an internal control for qPCR experiments, the following bacterial standard strains were used: Akkermansia muciniphila ATCC BAA-835, Faecalibacterium prausnitzii ATCC 27766, Bifidobacterium breve ATCC 15700, Lactobacillus acidophilus ATCC 4356, Escherichia coli ATCC 25922. Lactobacillus acidophilus and Bifidobacterium breve were cultured on Man Rogosa Dharpe (MRS) agar, A. muciniphila was grown on Brain Heart Infusion Agar (BHI) supplemented with $5 \mu \mathrm{g} / \mathrm{mL}$ hemin and $0.1 \mu \mathrm{g} / \mathrm{mL}$ Vitamin K1, F. prausnitzii, which is a strictly anaerobic bacteria was cultured on M2GSC medium with 30\% rumen fluid and $E$. coli culture was made on MacConkey Agar plates. All the bacterial cultures except E. coli were made under anaerobic conditions and incubated anaerobically (anaerobic jars with Anaerocult A gas packs; Oxoid). The DNA from pure cultures was extracted with High-Pure PCR Template Preparation Kit (Roche Diagnostics, Mannheim, Germany). The DNA amount was measured using Nano Drop ND-1000 (Thermo Scientific, Wilmington, DE). The copy number/ $\mu \mathrm{L}$ was calculated according to the concentration and molecular mass (number of base pairX660) depending on the genome size of the target bacteria. For the construction of the standard curves, 10 fold serial dilutions were made from pure DNA as previously described [21]. Standard curve was generated by using at least 4 of the standard dilutions with the appropriate efficiency number and used to determine copy numbers in samples (Figure 1). Input-output measurements were calculated and standardized in order to estimate copy number per gram of feces.

The amplification reaction was carried out in a total volume of $20 \mu \mathrm{L}$, consisted of $4 \mathrm{mM} \mathrm{MgCl} 2,0.25 \mu \mathrm{M}$ of each primer, $2 \mu \mathrm{L}$ of LightCycler FastStart DNA Master SYBR Green I (Roche) and $2 \mu \mathrm{L}$ of DNA template. Amplification involved an initial denaturation at $95^{\circ} \mathrm{C}$ for 10 min following by 45 cycles of denaturation at $95^{\circ} \mathrm{C} 10$ sec, annealing at specific annealing temperature for 5 sec, extension at $72^{\circ} \mathrm{C}$ for $10 \mathrm{sec}$. Melting curve analysis was also performed in order to determine specificity of the PCR reactions. Specific primer pairs and estimated annealing temperatures were presented in Table 1.

\section{Statistical Analysis}

The mean bacterial DNA and log transformed copy numbers and standard deviations were calculated. One-way ANOVA test was used to compare the data from each extraction method with others. A p value of $<0.05$ was used to establish significance. 


\section{RESULTS}

\section{Evaluation of DNA recovery and PCR inhibitors}

In order to evaluate the efficiency of DNA recovery $E$. coli NCTC 13846 cells were spiked into stool samples in a final concentration of 5X106 cfu/gr feces into $200 \mathrm{mg}$ weighted stool prior to extraction. DNA recovery rates were closer to the initial inoculum in PSP Spin Stool Kit and QIAamp DNA Stool Mini Kit (5.82 and 5.12 log10/ gr feces; respectively). However, in phenol-chloroform method the quantity was approximately 2 log lower than the initial concentration indicating the PCR inhibitors in extracted stool samples.

To determine the possible PCR inhibitors, known amount of E. coli NCTC 13846 DNA was spiked into PCR mastermix in a concentrations of $1.5 \times 106$ and $1.5 \times 103$ copy/ $\mu \mathrm{L}$. According to $\mathrm{qPCR}$ results determined by standard curves constructed by standard bacterial DNA (described in detail below), phenol-chloroform method was not efficient enough, due to the PCR inhibitors. Phenolchloroform method was failed to produce PCR products in compatible with the initial concentration in 5 of the samples (41.6\%).

\section{Quality and amount of isolated DNA}

Quality and quantity of isolated DNA were assessed by measuring the absorbance at 260 and $280 \mathrm{~nm}$ wavelengths by Nanodrop and by visualizing extracted DNA on agarose gel.

The samples extracted with PSP Spin Stool Kit comprised the best purity level (260/280) which is closer to 1.8 . All other samples were also within acceptable range except one sample extracted with phenol-chloroform method which is likely to have a high protein contamination.

The yield of the DNA was significantly lower in those extracted with phenol-chloroform method when compared to PSP Spin Stool Kit $(p=0.013)$. No significant difference was found between two commercial kits in terms of DNA amount.

\section{Specificity of the primers}

Specificity of each primer pairs were confirmed by both agarose gel elctrophoresis after conventional PCR and by observing one specific peak for each PCR product amplified by specific primer sets in Real-Time PCR melting curve analysis. All the PCR products amplified by specific primer were in expected sizes when agarose gel electrophoresis after amplification was performed. However the PCR bands were slightly faint in for all bacteria which were extracted by phenol-chloroform

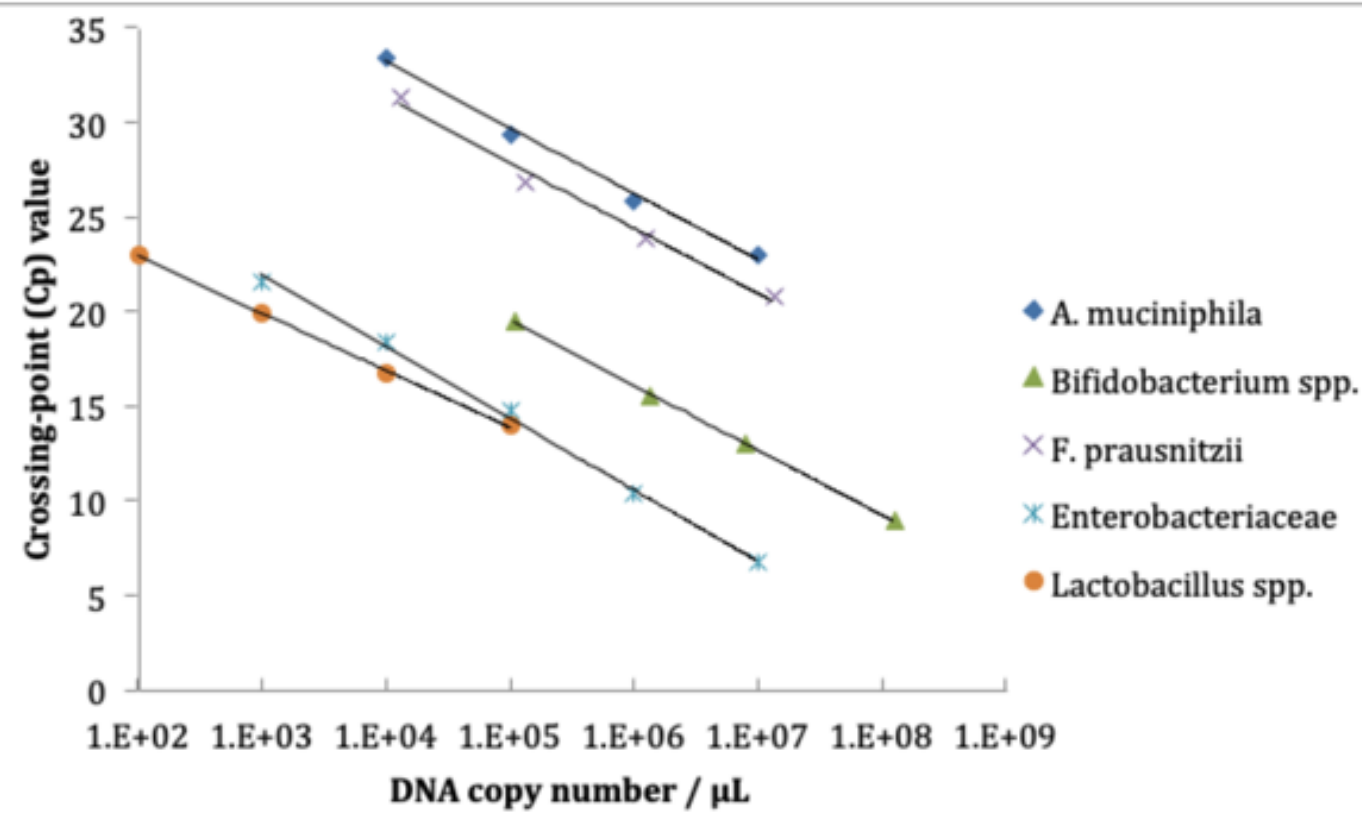

Figure 1. Bacterial DNA standards used in the study and crossing point values. 


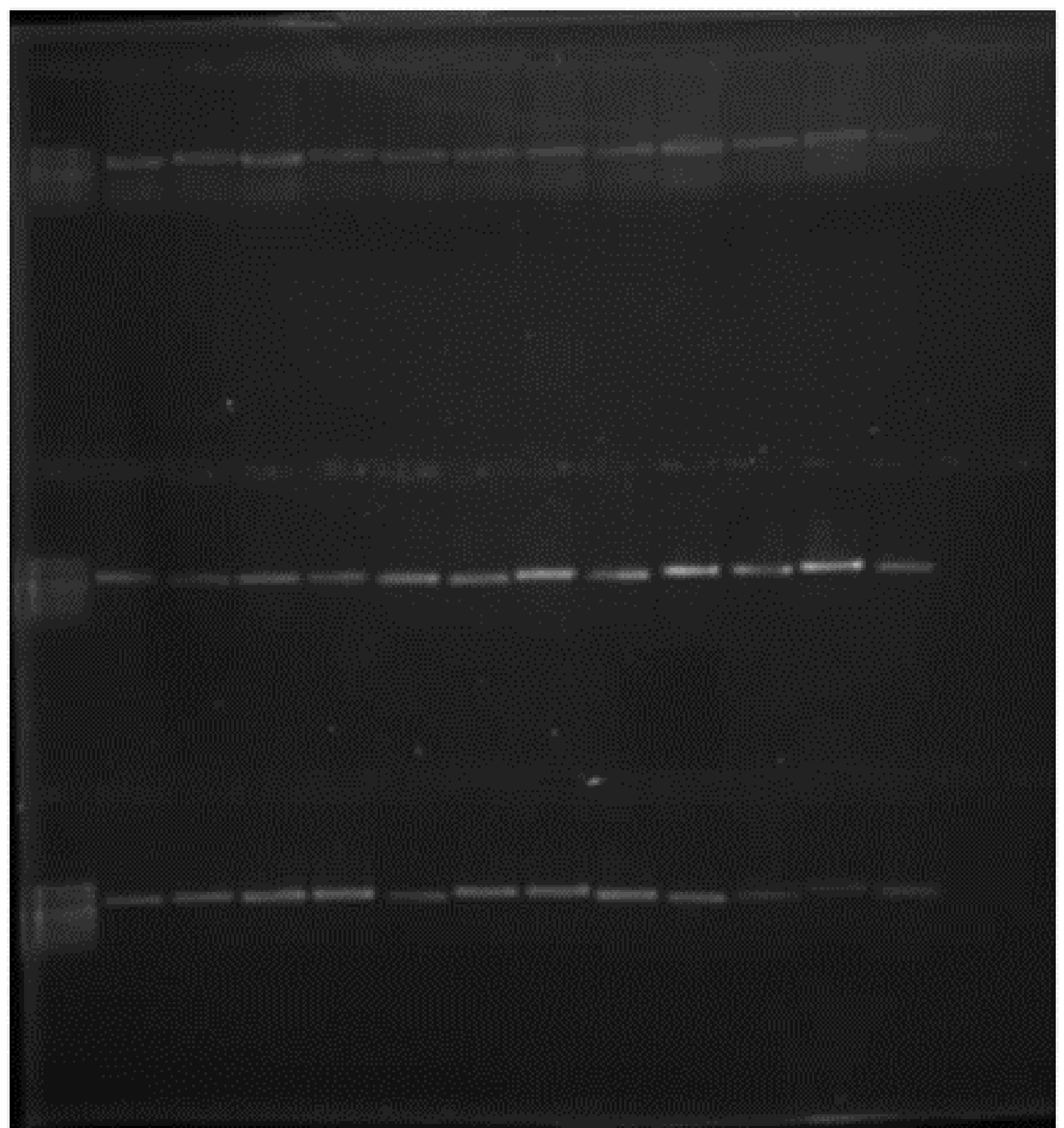

Figure 2. Agarose gel electrophoresis of A. muciniphila amplified products. First lane stands for phenol-chloroform extraction, second lane is PSP Spin Stool Kit and third lane is QIAamp DNA Stool Mini Kit.

method. A representative picture of agarose gel for $A$. muciniphila amplified products for each sample was presented in Figure 2.

\section{Absolute quantification by Real-Time PCR}

The mean $\log 10 / g r$ feces value for all bacterial groups, which were calculated and optimized by taking into account the input/output volumes in each reaction, was presented in Figure 3.
Total of 4 samples extracted by QiaAmp DNA Stool Mini Kit for quantification of Bifidobacterium spp. was failed with very high $\mathrm{Cp}$ values (greater than 40 ). Thus that 4 sample was not counted for the calculations for QiaAmp DNA Stool Mini Kit in Bifidobacterium quantification.

\section{DISCUSSION}

Advances in culture-independent molecular approach in microbiota studies have provide a better understanding of this complex, interactive ecosystem. Besides the 


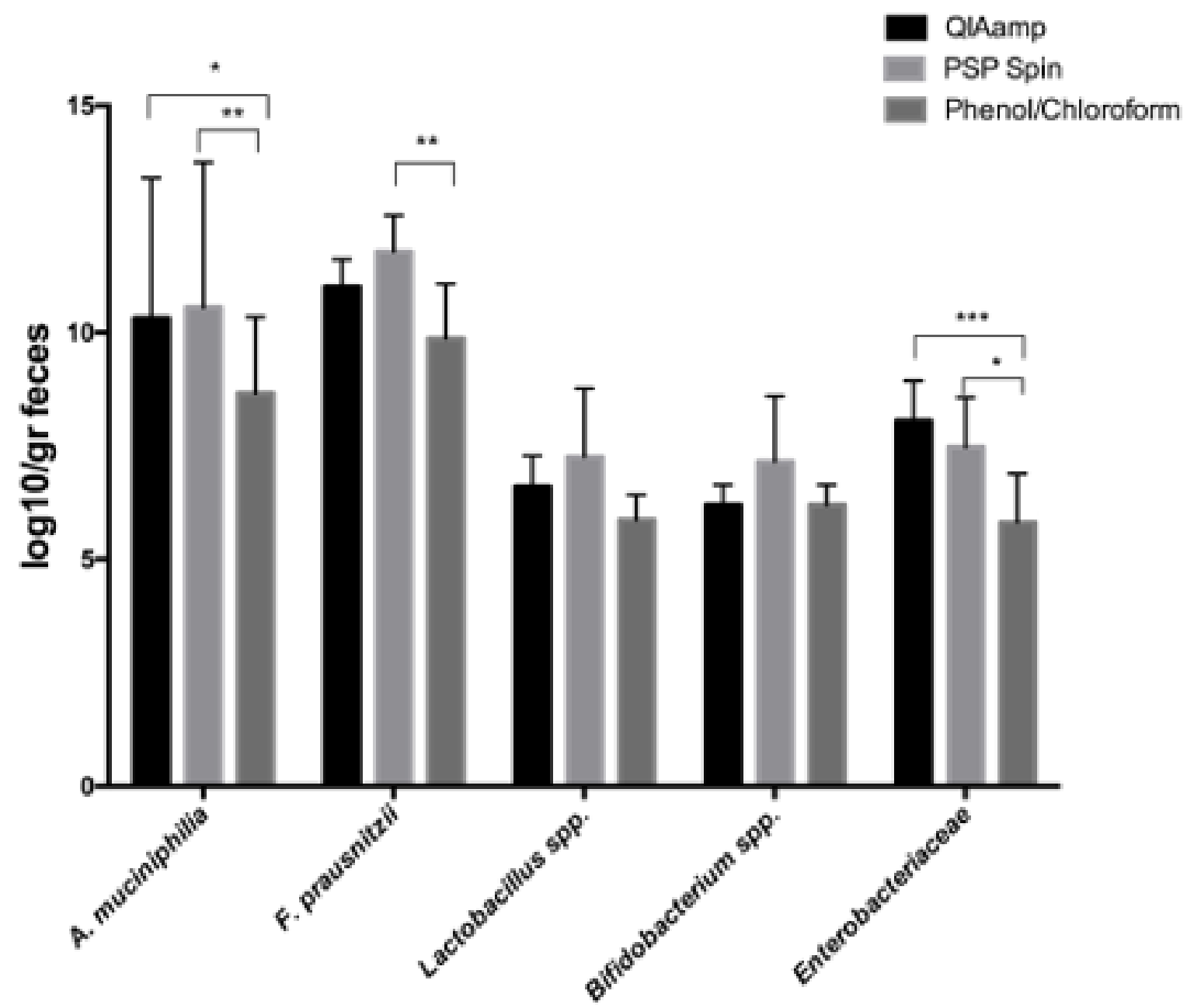

Figure 3. Comparison of log10/gram feces levels of bacterial groups between different extraction methods. Multiple comparisons were performed by two-way ANOVA. ${ }^{*} p<0.05 ;{ }^{* *} p<0.01 ;{ }^{* * *} p<0.001$.

many advantages of high throughput sequencing of $16 \mathrm{~S}$ rRNA region, it also has many biases and Real Time PCR identification of a specific target is still of importance due to its sensitivity and accuracy [13, 14, 16, 22]. Moreover, real-time PCR analysis should also be performed in order to support $16 \mathrm{~S}$ rRNA amplicon sequencing data, since it has limited discriminative power in species level $[11,12,23]$.

Independent from the molecular approach chosen for microbiota studies, the isolation of genomic DNA is a crucial step, which comprises isolation and purification of microbial DNA. Therefore, the present study aimed to evaluate the efficiency of in-house phenol-chloroform extraction method as well as two other commercial stool extraction kits. For this purpose both Gram-negative and Gram-positive bacteria, which were chosen due to their significant importance in clinical microbiota studi- es were used for Real-Time qPCR studies. Unlike Gramnegative bacteria, Gram-positive species has been known to be more resistant to cell lysis due to its higher concentration of peptides and cross-bond peptides in the cell wall [23]. Thus, extraction of Gram-positive important microbiota members, such as Lactobacillus and Bifidobacterium species, is more challenging.

Bifidobacterium and Lactobacillus are two important genera in intestinal microbiota, which can beneficially affect host by acetic acid and lactic acid production, inhibiting the overgrowth of the pathobionts and improving the intestinal barrier integrity [24]. Thus, these two genera are of importance in clinical microbiota studies. For this purpose, this study also evaluated the extraction efficiencies of the kits to isolate the members of these two genera by using genus specific primers as described in another study [16, 22]. 
As expected PSP Spin Stool Kit and QIAamp DNA Stool Mini Kit extracted the higher molecular weight DNA when compared to in-house phenol-chloroform extraction. In a large-scale study conducted by Henderson et al., they compared nine different, widely used stool extraction methods in terms of quantity and microbial community structure by using $\mathrm{QPCR}$ and pyrosequencing [25]. They also found similar results for both PSP Spin Stool Kit and QIAamp DNA Stool Mini Kit. Stool samples contain many substances, which could inhibit the PCR reactions [19]. Absorbance readings for protein contamination (A $260 / 280 \mathrm{~nm}$ ) indicate the DNA purity and should ideally be 1.8 for A $260 / 280 \mathrm{~nm}$. However in the study by Henderson et al. [25]., they found that the phenol-chloroform method most likely to fulfill the purity criteria when compared the other extraction methods in contrast with the present study. Phenol-chloroform extraction method they evaluated in their study included an additional step with polyethylene glycol different than the method in this study [26].

The present study includes the DNA recovery and quantification efficiency experiments by spiking the known amount of E. coli NCTC 13846 cells into stool samples and its DNA into PCR mixture. In spiking experiments, phenol-chloroform was failed to detect the initial concentration, which also indicates that the method is not sufficient to remove inhibitors. Therefore, additional steps to remove PCR inhibitors may be beneficial in phenol-chloroform extraction. The main advantage is the low-cost of in-house extraction methods such as phenol-chloroform (approximately 0.75 Euro per sample based on the pricing quote of 2016). The commercial kits were developed in order to overcome the biases and difficulties in phenol-chloroform extraction methods. According to the literature, stool DNA extraction with commercial kits has highly reproducible results, which eliminates an important bias in microbiome studies $[15,18,27]$. The results of the present study also indicated that, phenol-chloroform extraction method is not appropriate to use in Real-Time qPCR studies for absolute quantification, since it failed to eliminate PCR inhibitors. However it could be use in community analysis efficiently [25]. It can also be used in absence or presence of a gene of interest for its low cost and easy application. For a single extraction, processing times were approximately $20 \mathrm{~min}, 45 \mathrm{~min}$ and $50 \mathrm{~min}$ for phenol-chloroform, PSP Spin Stool Kit and QIAAmp DNA Stool Mini Kit, respectively.
Similar with the present results; Ariefdjohan et al. [28] also indicated that FASTDNA Spin kit was superior to QIAamp DNA Stool Mini Kit, since it was not able to extract DNA from all the bacteria in samples.

In the present study, the targeted bacteria were important for their health beneficial effects and significant features in human intestinal microbiota [2, 6, 23, 29]. Therefore, they might be targeted in most of the microbiota studies using Real Time PCR approach. According to the present results, commercial kits have better results for qPCR analysis and DNA recovery when compared to phenol-chloroform method. Particularly, PSP Spin Stool Kit extraction kit yielded with a higher purified DNA and higher yield when compared to other methods.

\section{References}

1. P.J. Turnbaugh, R.E. Ley, M. Hamady, C.M. Fraser-Liggett, R. Knight, J.I. Gordon, The human microbiome project, Nature, 449 (2007) 804-810.

2. F. Guarner, J.R. Malagelada, Gut flora in health and disease, Lancet, 361 (2003) 512-519.

3. M.C. Abt, D. Artis, The intestinal microbiota in health and disease: the influence of microbial products on immune cell homeostasis, Curr. Opin. Gastroenterol., 25 (2009) 496-502.

4. N.A. Bokulich, J. Chung, T. Battaglia, N. Henderson, M. Jay, H. Li , A. D. Lieber, et al., Antibiotics, birth mode, and diet shape microbiome maturation during early life, Sci. Transl. Med., 8 (2016) 343 ra382.

5. P.J. Turnbaugh, M. Hamady, T. Yatsunenko, B.L. Cantarel, A. Duncan, R.E. Ley, M.L. Sogin, et al., A core gut microbiome in obese and lean twins, Nature, 457 (2009) 480-484.

6. P.J. Turnbaugh, R.E. Ley, M.A. Mahowald, V. Magrini, E.R. Mardis, J.I. Gordon, An obesity-associated gut microbiome with increased capacity for energy harvest, Nature, 444 (2006) 1027-1031.

7. G.M. Weinstock, Genomic approaches to studying the human microbiota, Nature, 489 (2012) 250-256.

8. E.R. Mardis, Next-generation DNA sequencing methods, Annu. Rev. Genomics. Hum. Genet., 9 (2008) 387-402.

9. R.E. Ley, F. Backhed, P. Turnbaugh, C.A. Lozupone, R.D. Knight, J.I. Gordon, Obesity alters gut microbial ecology, Proc. Natl. Acad. Sci. U S A., 102 (2005) 11070-11075.

10. I. Sekirov, S.L. Russell, L.C. Antunes, B.B. Finlay, Gut microbiota in health and disease, Physiol. Rev., 90 (2010) 859-904

11. R. Poretsky, R.L. Rodriguez, C. Luo, D. Tsementzi, K.T. Konstantinidis, Strengths and limitations of 16S rRNA gene amplicon sequencing in revealing temporal microbial community dynamics, PLoS One, 9 (2014) e93827.

12. A. Rintala, S. Pietila, E. Munukka, E. Eerola, J.P. Pursiheimo, A. Laiho, S. Pekkala, et al., Gut Microbiota Analysis Results Are Highly Dependent on the 16S rRNA Gene Target Region, Whereas the Impact of DNA Extraction Is Minor, J. Biomol. Tech., 28 (2017) 19-30. 
13. X. Guo, X. Xia, R. Tang, J. Zhou, H. Zhao, K. Wang Development of a real-time PCR method for Firmicutes and Bacteroidetes in faeces and its application to quantify intestinal population of obese and lean pigs, Lett. Appl. Microbiol., 47 (2008) 367-373.

14. S.J. Ott, M. Musfeldt, U. Ullmann, J. Hampe, S. Schreiber, Quantification of intestinal bacterial populations by realtime PCR with a universal primer set and minor groove binder probes: a global approach to the enteric flora, J. Clin. Microbiol., 42 (2004) 2566-2572.

15. F. Fouhy, A.G. Clooney, C. Stanton, M.J. Claesson, P.D.Cotter, $16 S$ rRNA gene sequencing of mock microbial populations impact of DNA extraction method, primer choice and sequencing platform, BMC Microbiol., 16 (2016) 123.

16. T. Matsuki, K. Watanabe, J. Fujimoto, Y. Miyamoto, T. Takada, K. Matsumoto, H. Oyaizu, et al., Development of 16S rRNAgene-targeted group-specific primers for the detection and identification of predominant bacteria in human feces, Appl. Environ. Microbiol., 68 (2002) 5445-5451.

17. T. Rinttila, A. Kassinen, E. Malinen, L. Krogius, A. Palva, Development of an extensive set of $16 \mathrm{~S}$ rDNA-targeted primers for quantification of pathogenic and indigenous bacteria in faecal samples by real-time PCR, J. Appl. Microbiol., 97 (2004) 1166-1177.

18. S. Zielinska, P. Radkowski, A. Blendowska, A. LudwigGalezowska, J.M. Los, M. Los, The choice of the DNA extraction method may influence the outcome of the soil microbial community structure analysis, Microbiologyopen, 6 (2017).

19. C.G. Thornton, S. Passen, Inhibition of PCR amplification by phytic acid, and treatment of bovine fecal specimens with phytase to reduce inhibition, J. Microbiol. Methods., 59 (2004) 43-52.

20. E.G. Zoetendal, K. Ben-Amor, A.D. Akkermans, T. Abee, W.M. de Vos, DNA isolation protocols affect the detection limit of PCR approaches of bacteria in samples from the human gastrointestinal tract, Syst. Appl. Microbiol., 24 (2001) 405 410.

21. C. Ozkul, M. Yalinay, T. Karakan, G. Yilmaz, Determination of certain bacterial groups in gut microbiota and endotoxin levels in patients with nonalcoholic steatohepatitis, Turk. J. Gastroenterol., 28 (2017) 361-369.
22. H. Maeda, C. Fujimoto, Y. Haruki, T. Maeda, S. Kokeguchi, M. Petelin, H. Arai, et al., Quantitative real-time PCR using TaqMan and SYBR Green for Actinobacillus actinomycetemcomitans, Porphyromonas gingivalis, Prevotella intermedia, tetQ gene and total bacteria, FEMS Immunol. Med. Microbiol., 39 (2003) 81-86.

23. P. Hugon, J.C. Lagier, C. Robert, C. Lepolard, L. Papazian, D. Musso, B. Vialettes, et al., Molecular studies neglect apparently gram-negative populations in the human gut microbiota, J. Clin. Microbiol., 51 (2013) 3286-3293.

24. K.A. Le, Y. Li, X.J. Xu, W.T. Yang, T.T. Liu, X.N. Zhao, Y.G. Tang, et al., Alterations in fecal Lactobacillus and Bifidobacterium species in type 2 diabetic patients in Southern China population, Front. Physiol., 3 (2013).

25. G. Henderson, F. Cox, S. Kittelmann S, V.H. Miri, M. Zethof, S.J. Noel, G.C. Waghorn, et al., Effect of DNA extraction methods and sampling techniques on the apparent structure of cow and sheep rumen microbial communities, PLoS One, 8 (2013) e74787.

26. T. Lueders, M. Manefield, M.W. Friedrich, Enhanced sensitivity of DNA- and rRNA-based stable isotope probing by fractionation and quantitative analysis of isopycnic centrifugation gradients, Environ. Microbiol., 6 (2004) 73-78.

27. M. Li, J. Gong, M. Cottrill, H. Yu, C. de Lange, J. Burton, E. Topp, Evaluation of QIAamp (R) DNA Stool Mini Kit for ecological studies of gut microbiota, J. Microbiol. Methods., 54 (2003) 13-20.

28. M.W. Ariefdjohan, D.A. Savaiano, C.H. Nakatsu, Comparison of DNA extraction kits for PCR-DGGE analysis of human intestinal microbial communities from fecal specimens, Nutr. J., 9 (2010) 23.

29. M. Remely, E. Aumueller, C. Merold, S. Dworzak, B. Hippe, J. Zanner, A. Pointner, et al., Effects of short chain fatty acid producing bacteria on epigenetic regulation of FFAR3 in type 2 diabetes and obesity, Gene, 537 (2014) 85-92. 